\title{
Diversity of thermophilic archaea and their biotechnological uses
}

\author{
Rümeysa Gülsu ÖZKAN *1, Gamze BAŞBÜLBÜL ${ }^{1,2}$ \\ ORCID: 0000-0002-2379-0696; 0000-0001-8151-6321
}

\author{
${ }^{1}$ Aydın Adnan Menderes University, Institute Of Health Sciences, Molecular Biotechnology Department, 09000 Aydın, \\ Turkey \\ ${ }^{2}$ Aydın Adnan Menderes University, Faculty of Science and Letters, Department of Molecular Biology, 09000 Aydın,
} Turkey

\begin{abstract}
Archaea, which constitute one of the three major domains of living things, in terms of both biochemical properties and structural features, are prokaryotic cell types that are separated from eukaryotes and bacteria. The vast majority of members of Archea survive in extreme ambient conditions thanks to their metabolic and molecular adaptations. Typical environments in which pure cultures of archaea species isolated; are hot springs, hydrothermal vents, solfataras, salt lakes, soda lakes. Microbial diversity analysis can be performed both with microbiology-based culture-dependent methods and culture-independent methods using molecular techniques. However, it is still difficult to create conditions in very hot and pressurized environments in laboratory environments and many different taxa can be overlooked. It is not possible to determine archaea types that have not yet been cultured in studies based on culture. Therefore, over the past two decades, the use of molecular techniques involving PCR-based amplification of 16S rRNA genes in environmental samples allows a culture-independent evaluation of microbial diversity. As a result of archaea's ability to function at nearly limit values in terms of temperature, salinity and $\mathrm{pH}$, extremophilic enzymes (extremozymes) are now found in many applications. In this review, general properties of thermophilic archaea, archaeal diversity studies independent of culture, and usage areas of archaeal enzymes in biotechnology are discussed.
\end{abstract}

Keywords: Archaea, thermophilic and hyperthermophilic, culture independent methods, archaeal extremosimes

\section{Termofilik arkelerin çeşitliliği ve biyoteknolojide kullanım alanları}

\section{Özet}

Arkeler canlıların üç büyük domaininden birini oluşturan, biyokimyasal özellikleri bakımından hem bakterilerden hem de ökaryotlardan farklı olan, prokaryotik hücre tipinde tek hücreli canlılardır. Arkeler pek çok canlının hayatta kalamayacağı aşırı sıcak, aşırı soğuk ve aşırı tuzlu ve benzeri ekstrem ortamlarda yaşayabilirler. Yakın zamana kadar arkelerin sadece ekstrem ortam koşullarında yaşayabildikleri zannedilirken, son dönemlerde yapılan çalışmalarda arkelerin başka canlı gruplarının bulunduğu normal yaşam ortamlarında da geliştikleri tespit edilmiştir. Arke türlerinin saf kültürlerinin izole edildiği tipik ortamlar; kaplıcalar, hidrotermal bacalar, solfatoralar, tuz gölleri, soda gölleridir. Mikrobiyal çeşitlilik analizleri hem mikrobiyoloji temelli kültür bağımlı yöntemlerle hem de moleküler teknikler kullanılarak kültürden bağımsız yöntemlerle yapılabilmektedir. Ancak yine de çok sıcak ve basıç̧lı çevrelerdeki koşulları laboratuvar ortamlarında oluşturmak zordur ve birçok farklı takson gözden kaçabilir. Kültüre bağlı olarak yapılan çalışmalarda henüz kültüre edilmemiş arke türlerinin belirlenmesi söz konusu değildir. Bu nedenle son yirmi yılda, çevresel örneklerdeki 16S rRNA genlerinin PCR-bazlı amplifikasyonunu içeren moleküler tekniklerin kullanılması, kültürden bağımsız bir mikrobiyal çeşitlilik değerlendirmesine izin vermektedir.

\footnotetext{
* Corresponding author / Haberleşmeden sorumlu yazar: Tel.: +905412302093; Fax.: +9 +902562146687; E-mail: gulsuozkaann@ gmail.com

(C) Copyright 2021 by Biological Diversity and Conservation Geliş tarihi: 17.08.2020; Yayın tarihi: 15.04.2021
} 
Arkelerin sıcaklık, tuzluluk ve $\mathrm{pH}$ açısından neredeyse sınır değerlerde işlev gösterme kabiliyetlerinin bir sonucu olarak, ekstremofilik enzimleri (ekstremozimleri) günümüzde birçok uygulamada kullanım alanı bulmaktadır. $\mathrm{Bu}$ derlemede termofilik arkelerin genel özelliklerine, kültürden bağımsız arkeal çeşitlilik çalışmalarına ve arke enzimlerinin biyoteknolojide kullanım alanlarına değinilmiştir.

Anahtar kelimeler: arke, termofilik ve hipertermofilik, kültür bağımsız yöntemler, arkeal ekstremozimler

\section{Giriş}

Arkeler canlıların üç büyük âleminden birini oluşturan biyokimyasal özellikleri bakımından hem bakterilerden hem de ökaryotlardan farklı olan, prokaryotik hücre tipinde tek hücreli canlılardır. Arkeler çoğu canlının hayatta kalamayacağı aşırı sıcak, aşırı soğuk ve aşırı tuzlu gibi ekstrem ortamlarda yaşayabilirler. Onları diğer canlılardan farklı ve özel kılan da bu özellikleridir. Yakın zamana kadar arkelerin sadece zor ortam koşullarda yaşayabildikleri zannedilirken, son dönemlerde yapılan çalışmalarla arkelerin başka canlı gruplarının yaşayabildiği normal yaşam ortamlarında da bulundukları tespit edilmiştir. Arke domaini kendi içinde yaşam alanlarına göre sınıflandırılabilir; Alkalifiller (Alkali sevenler): Bu türler 9 ile 11 arasındaki pH aralıklarında yaşamaktadırlar. Asidofiller (Asit sevenler): Alkalifillerin tam tersi olarak bu arkeler çok düşük $\mathrm{pH}$ aralıklarında yaşayabilirler. Halofiller (Tuz sevenler): Kızıldeniz'de, Türkiye'de Tuz Gölü'nde, Ürdün ve İsrail arasındaki Ölü Deniz'de Amerika'nın Utah eyaletinde bulunan Büyük Tuz Gölü'nde, Kaliforniya'nın Owens Gölü gibi tuz oranına çok yüksek olan (\%36 ve üzeri tuzluluk) yerlerde yaşayabilmektedirler. Metanojenik arkeler: Bataklıklarda, pis sularda, çiftlik gübresinde, çöplerde ve otçul canlıların sindirim sistemlerinde bol miktarda bulunmaktadırlar. Termofiller-Hipertermofiller (Sicak sevenler): Terminolojik olarak, $50{ }^{\circ}$ C'den daha yüksek bir maksimum büyüme sıcaklığına sahip organizmalar, termofiller olarak tanımlanmaktadır. Kristjansson ve Stetter'in yaptıkları çalışmalar sonucunda optimal olarak $80^{\circ} \mathrm{C}^{\prime}$ nin üzerinde büyüyen mikroorganizmalar hipertermofiller olarak kabul edilmektedir. Günümüzde bilinen, sıcaklık açısından üst yaşam sınırı olan $130^{\circ} \mathrm{C}$ 'ye en yakın sıcaklıkta yaşayabilen bir Pyrolobus türü olan Strain 121'dir.Bunlara ek olarak bazı metanojen hipertermofilik türler sıcaklığın $110^{\circ} \mathrm{C}$ olduğu volkanik bölgelerde bulunurlar [1].

Psikrofiller (Soğuk sevenler): Soğuk seven arke türleri suyun donma noktasındaki aşırı yaşam şartlarına direnç gösteren arkelerdir. Soğuk seven bu arkelerin çoğu sıcaklığı $5^{\circ} \mathrm{C}$ 'nin altındaki yaşam alanlarında yaşarlar.

\subsection{Arkelerin Tarihi}

Dünyaca ünlü moleküler biyolog Carl Woese 1976'da 60 farklı bakteri türünün rRNA'larını analiz ederek bu diziler arasında farklılıklar olabileceğini ortaya koymuştur. Bakterilere çok benzeyen bazı mikroorganizmaların bakterilerden farklı olarak metan ürettiklerini ve bakterilerde görülen rRNA özelliklerinin bu metanojenlerde görülmediğini fark etmiştir. İlk yıllarda Carl Woese'un, çalışmaları sonucu bu kültürdeki mikroorganizmalar "Archaeabacteria" olarak tanımlanmıştır. Bu sayede bakterilerin filogenetik sınıflandırılması mümkün hale gelmiştir. 31 Ocak 1980'de yaşamın 3 ana domainden meydana geldiği tarihe geçmiştir [2].

\section{Bacteria $\quad$ Archaea Eukaryota}

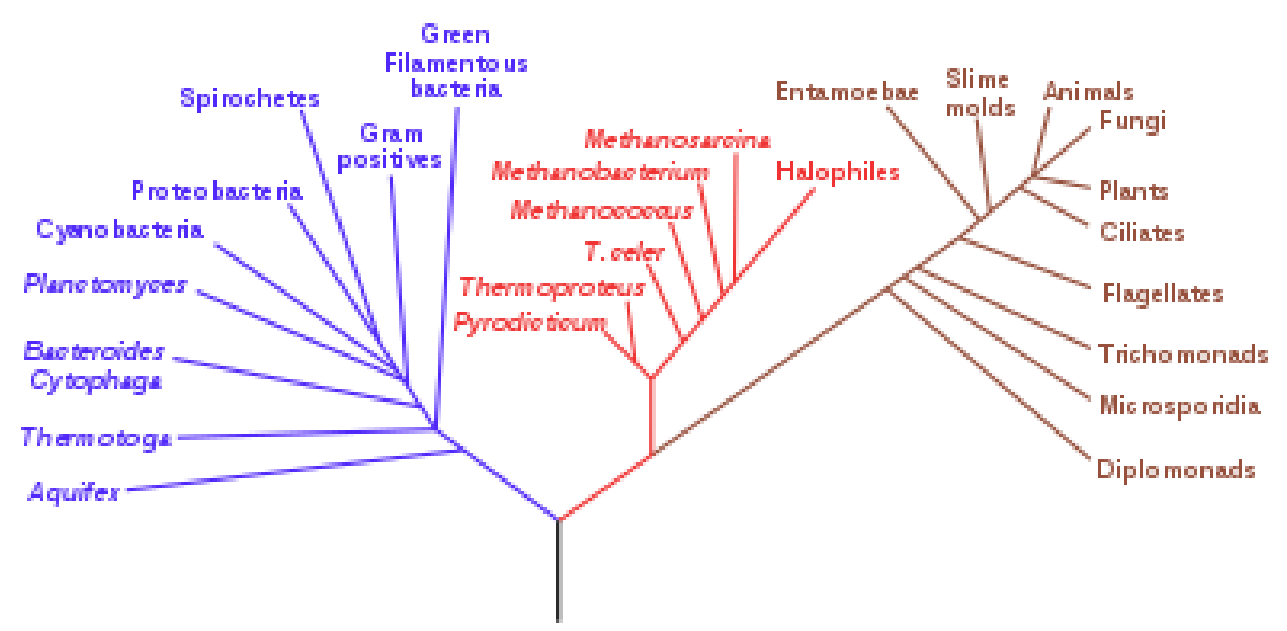

Şekil 1. Yaşamın 3 temel domaini [2]

Arkeleri diğer canlılardan ayıran özellikler olan; ekstrem ortamlarda yaşayabilmesi, metan üretimi gibi özelliklere ek olarak arkeler, bakteri ve ökaryot domaininden hem yapısal hem de işlevsel açıdan oldukça farklı özellikler taşımaktadır. 


\subsection{Arkelerin Taksonomisi}

Arkeler filogenetik olarak 5 temel şubeye ayrılmaktadırlar:

Crenarchaeota: Kültürü yapılan arkeler arasında Crenarchaeota üyeleri çoğunlukla, bilinen en yüksek sıcaklık derecelerinde üreyebilen hipertermofilik mikroorganizmaları içermektedir.

Euryarchaeaota: Crenarchaeotalar gibi Euryarchaeotaların da büyük bir kısmı ekstrem ortamlarda yaşamaktadır. Bu şube metanojenik Archaea ve bazı ekstrem halofilik Archaea cinslerini içermektedir.

Korarcaheota: Korachaeota ilk olarak Yellowstone'da bir sıcak su kaynağında yaşayan mikroorganizmaların metagenomik analizleri yapılarak keşfedilmiştir. Bu organizmaların saf kültürleri bulunmamaktadır.

Nanoarcaheota: Bir diğer Archaeal şube Nanoarchaeaota'dır. Bu şubenin tek cinsi olan Nanoarchaeum bir Crenarchaeota olan Ignicoccus hücrelerine tutunarak yaşayan çok küçük bir parazitik prokaryottur.

Thaumarchaeota: Cenarchaeum symbiosum 'un sekanslanması sonucu keşfedilmiş olan ve Archaea domainine son eklenen şube Thaumarchaeota diğer filumlardan oldukça farklıdır. Thaumarchaea, su ve karasal ortamlardaki önemli amonyak oksitleyicilerdir ve nitrifikasyonda yer aldığı tespit edilen ilk arkedir. Genellikle denizlerde ve açık okyanuslarda bulunurlar [3].

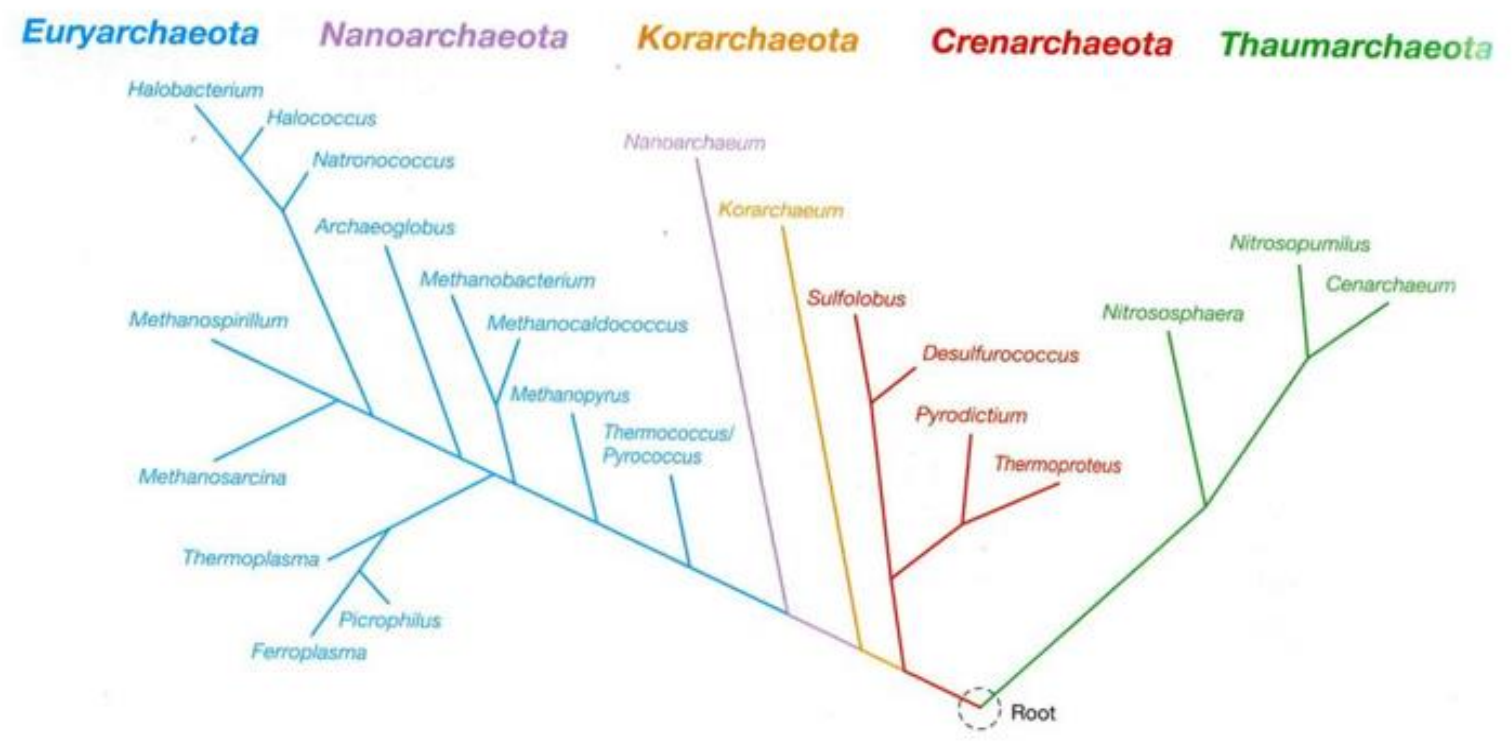

Şekil 2. Archaea filogenetik ağaç [2]

\subsection{Termofilik ve Hipertermofilik Mikroorganizmalar}

Terminolojik olarak, $50^{\circ} C^{\prime}$ den daha yüksek bir maksimum büyüme sıcaklığına sahip organizmalar, termofiller olarak tanımlanmaktadır. Kristjansson ve Stetter [21] 'in yaptıkları çalışmalar sonucunda optimal olarak $80^{\circ}$ C'nin üzerinde büyüyen mikroorganizmalar hipertermofiller olarak kabul edilmektedir. Günümüzde bilinen, sıcaklık açısından üst yaşam sınırı olan $130^{\circ} \mathrm{C}$ 'ye en yakın sıcaklıkta yaşayabilen bir Pyrolobus türü olan Strain $121^{\prime}$ dir ve Arke domainin üyesidir. Bunlara ek olarak bazı metanojen hipertermofilik türler sıcaklığın $110^{\circ} \mathrm{C}$ olduğu volkanik bölgelerde bulunurlar [4].

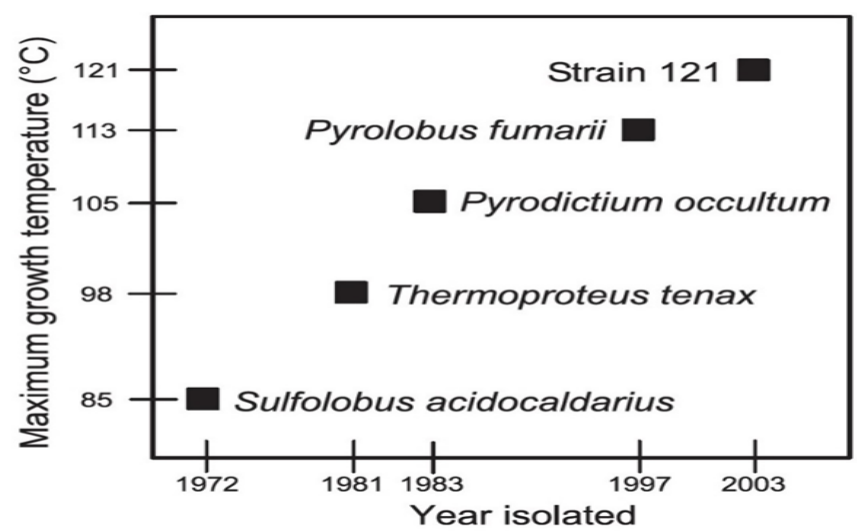

Şekil 3. Bazı hipertermofilik mikroorganizmaların en yüksek büyüme sıcaklıkları [5] 
1972'de Brock ve arkadaşları tarafından bildirilen ve o tarihe kadar bilinen en yüksek sıcaklığa sahip olan mikroorganizma Sulfolobus acidocaldarius olarak tanımlanmıştır. Bu tür ilk olarak bakteri domaininde yer almıştır ancak 1980'de yaşamın üç ana domainden meydana geldiğinin tarihe geçmesiyle birlikte S.acidocaldarius ' un Archaea domainine ait olduğu belirlenmiştir. Bu tür, optimum olarak $75-80^{\circ} \mathrm{C}$ sıcaklıkta gelişmektedir. Hipertermofiller ise Zillig ve ark. tarafindan 1981'de keşfedilmiştir [2][6].

\subsection{Termofilik Arkelerin Habitatları}

Termofilik arkeler sıcak çevrelerden izole edilmektedirler. Bu çevreler doğal veya yapay kaynaklar olabilir. Termofilik arkeal türlerin saf kültürlerinin izole edildiği tipik ortamlar;

- Kaplıcalar: Sıcak yeraltı sularından yararlanmak için yeryüzüne çıktıkları kaynakların çevresine kurulan hamam görünümündeki tesislere denir.

- Hidrotermal bacalar: Hidrotermal bacaların iç kısımlarında sıcaklık ortalama $350-400{ }^{\circ} \mathrm{C}$ arasındadır. Ağız kısımlarında ise ortalama $150^{\circ} \mathrm{C}$ dolaylarındadır.

- Solfatoralar: Fümerol (latince) çoğunlukla yer kabuğu sıcaklığının çok yüksek olduğu, yakın dönemde etkin yanardağların yer aldığı bölgelerde, karbondioksit, sülfürdioksit, hidrojenklorid ve hidrojen-sülfit gibi gazların, buhar şeklinde salındığı, yer kabuğundaki açıklıklardır [7].

- $\quad$ Derin ve sı̆̆ hidrotermal sistemler [8]

Bununla birlikte termofiller; kompost yığınları ve kömür atık yığınları gibi ortamlarda da bulunabilirler. İnsan yapımı termal ortamlar olarak; evsel ve endüstriyel sıcak su sistemleri, yüksek sıcaklıktaki endüstriyel prosesler, kâğıt işleme makineleri, yiyecek işleme tesisleri örnek verilebilir.

\subsubsection{Termofilik Arkelerin İzolasyonu}

Termofilik ve hipertermofilik arkeler genellikle sıcak su kaynaklarından izole edilmektedirler. Sicak su kaynakları, dünyanın çok değişik yerlerinde bulunur. Biyologların çoğu 19. yüzyılın ortalarından sonra termal sularda yaşayan organizmalar üzerinde gözlemler yapmışlardır. Dünya üzerindeki sıcak su kaynakları Batı Amerika, Orta Afrika, Yeni Zelanda, İzlanda, Japonya, İtalya, Endonezya, Orta Amerika, Orta Afrika gibi ülkelerin bulunduğu geniş bir alanda bulunur. Ancak, termal habitatlarda yaşayan mikroorganizmalar üzerine kapsamlı çalışmalar uzun yıllar Yellow Stone Ulusal Parkında yapılmıştır. Bu park dünyada termal özelliklere sahip en önemli yerlerden biridir. Termofilik arke çeşitliliği hem mikrobiyolojik kültür temelli hem de moleküler yöntemlere bağlı yaklaşımlar kullanılarak belirlenebilmektedir. Termofilik arkelere özgü kültür ortamı hazırlanarak yapılan mikrobiyolojik temelli yöntemlerle; yüksek sıcaklığa dayanıklı ve bu koşullarda jelleşen yeni nesil katılaştırıcı ajan "gelrite" kullanılarak yapılabilir. Son zamanlarda çalışmalarda yaygın kullanılan yöntem ise kültür ortamından bağımsız olarak yapılan moleküler yöntemlerle PCR-bazlı teknikler kullanılarak termofilik arkelerin tanısını ve karakterizasyonunu gerçekleştirmektir.

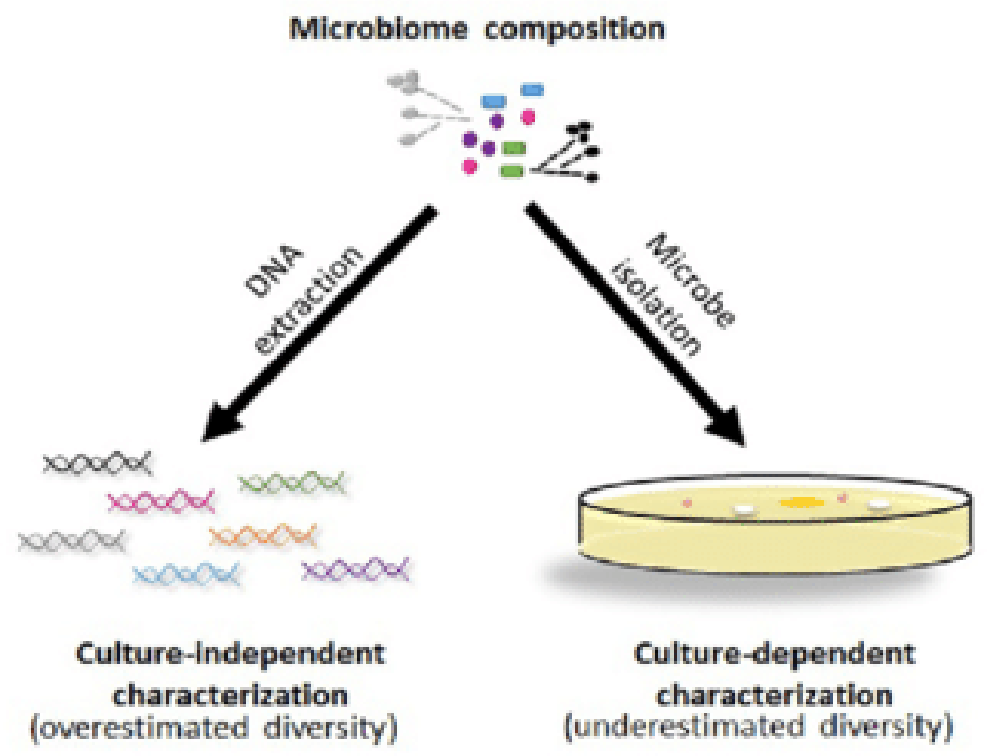

Şekil 4. Kültüre bağımlı ve kültürden bağımsız yöntemlerle prokaryotik çeşitliliğinin değerlendirilmesi [9] 


\subsubsection{Termofilik Arke Çeşitliliğinin Belirlenmesi}

Son yirmi yılda, 16S rRNA genlerinin PCR-bazlı amplifikasyonunu içeren moleküler tekniklerin kullanılması, kültürden bağımsız bir mikrobiyal çeşitlilik değerlendirmesine izin vermiştir. Bu tür teknikler ile, okyanus suları, göl suları ve toprak gibi normal habitatlarda çoğunlukla kültürlenmemiş arkelerin geniş bir dağılımı gözlenmiştir. Bu yöntemle,kültüre edilmemiş mikroorganizmalar için filogenetik ağaçlar elde etmek mümkün hale gelmiştir. Buna dayanarak Pace ve arkadaşları ilk olarak 1986'da SSU rRNA'lar için tasarlanan primerleri kullanarak PCR yöntemiyle çevresel araştırmalara başlamışlardır [10].

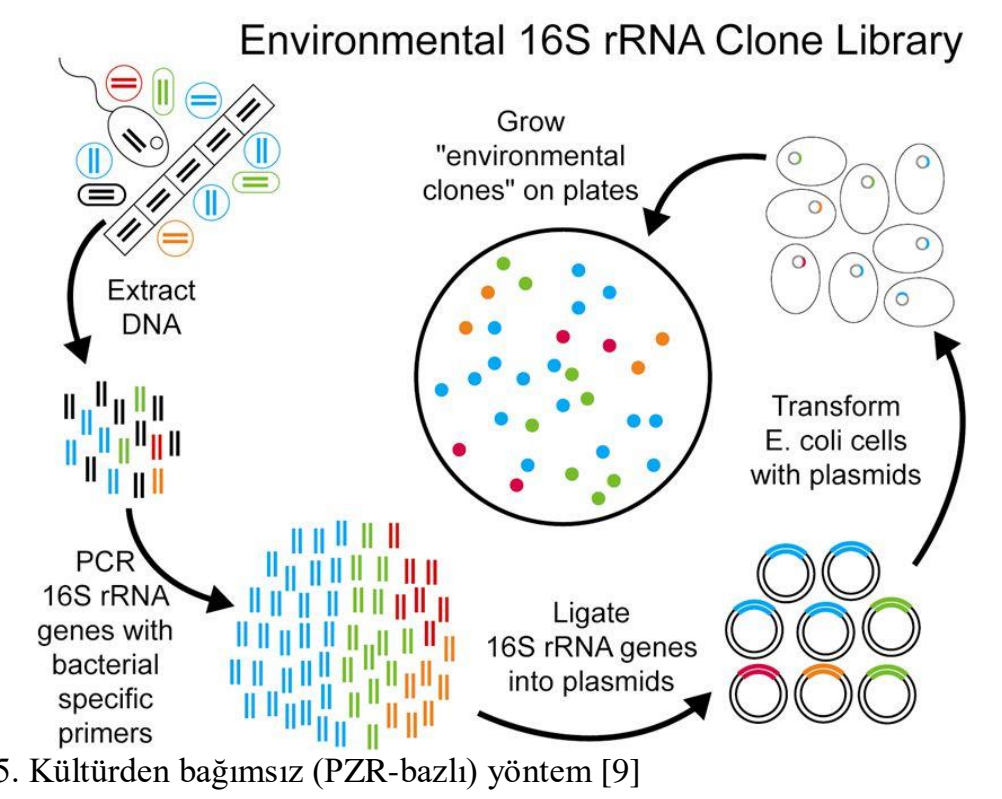

1.DNA ekstraksiyonu 2.Termofilik arkelere spesifik primerler ile 16S rRNA genlerinin PZR ile amplifikasyonu . 3.16S rRNA genlerinin plazmitlere aktarımı 4. Plazmitlerin E.coli hücrelerine transformasyonu 5.rDNA klonlarının bulunduğu klon kütüphanesi

\subsection{Termofilik Arkelerde Yüksek Sicaklık Adaptasyonu}

Termofilik arkeler diğer pek çok mikroorganizmanın hayatlarını sürdüremedikleri yüksek sıcaklıklarda yaşayabilen organizmalardır. Termofilik arkelerin; hücre zarları, enzimleri, nükleik asitleri, proteinleri ve bir takım hücre yapıları yaşayabildikleri yüksek sıcaklıklara dayanabilir yapıdadırlar. Yüksek sıcaklıklarda yaşayabilmeleri için DNA, protein ve hücre membran yapılarında farklı mekanizmalar geliştirerek bir takım yapısal değişikliklere uğramışlardır. Yüksek sıcaklık membranların akışkanlığını arttırır. Optimum membran akışkanlığı sağlamak için hücre, lipitlerin miktarını ve türünü (örneğin doymuş ve doymamış) içeren membran bileşimini ayarlamalıdır. Sıcaklık da proteinlerin yapısını ve işlevini etkiler. Proteinlerin yüksek sıcaklıklarla başa çıkmak için geliştirdiği yollar arasında iyon çifti içeriğinin arttırılması, hidrojen bağları ve disülfit köprülerinin arttırılması ve oda sıcaklığında esnekliğin azaltılması gibi adaptasyonlar bulunmaktadır. Stres faktörlerine maruz kalan birçok biyolojik yapı strese karşı belirli yanıtlar ve bazı maddeler oluşturur. Bu maddelerin başında ise stres proteinleri olarak da adlandırılan 1sı şok proteinleri (Hsps) gelir. Bu bilgiler ışığında termofillerde ısı şok protein içeriğinin arttığı da belirlenmiştir. Ayrıca termofiller ve hipertermofiller tarafından üretilen proteinler, mezofilik proteinlere göre denatürasyona karşı daha dirençlidir. Bununla birlikte sadece hipertermofillerde bulunduğu düşünülen özel bir protein sayesinde DNA'nın degrade olmaması söz konusudur. Tüm hipertermofiller ters DNA giraz olarak adlandırılan bir DNA topoizomeraz üretirler [11][12][13].

Arke ve bakterilerin termostabilitesini anlamak için, membran kompozisyonları üzerinde yoğunlaşmak gerekir. Arkelerin hücre zarı genellikle eter-bağlardan oluşurken bakteriyel hücre zarı ester-bağlarından oluşmaktadır. Eterbağları gliserol ve hidrokarbonlar arasında olurken, ester bağları yağ asitleri ve gliserol arasında olur. Arkelerin hücre membranı, kimyasal ve termodinamik olarak bakteri hücre zarından daha stabildir.

\subsection{Oksijen İlişkileri Açısından Termofilik Arkeler}

Termofilik arkeler genel olarak zorunlu veya fakültatif anaerobiktirler. Pekçok hipertermofil ise, kemootorotroftur. Tek karbon kaynağı olarak $\mathrm{CO}_{2}^{\prime}$ 'yi ve enerji kaynağı olarak inorganik redoks reaksiyonlarını kullanırlar. Ayrıca, tüm hipertermofiller ve birçok termofil türü fotosentetik yerine kemosentetiktir, güneş enerjisini kullanmak yerine çözünmüş organik ve inorganik bileşiklerin oksidasyonu veya bu bileşikleri tüketerek enerji üretir. 
Bununla birlikte, kültürdeki termofillerin ve hipertermofillerin çoğu, kükürt redoks sistemindeki türler arasında elektron transferinden faydalanır. Bazı hipertermofilik arkeler ise metan üretirler. (Tablo 1).

Tablo 1 Termofilik ve hipertermofilik arkelerin metabolik özellikleri ve taksonomileri

\begin{tabular}{|c|c|c|c|}
\hline \multirow{12}{*}{$\begin{array}{l}\text { Tür } \\
\text { Methanobacteriumthermophilum } \\
\text { Methanococcus } \\
\text { thermolithotrophicus } \\
\text { Methanoculleus } \\
\text { thermophilicum } \\
\text { Methanosarcina } \\
\text { thermophila } \\
\text { Palaecoccus } \\
\text { ferrophilus } \\
\text { Picrophilus } \\
\text { ashimae } \\
\text { Sulfulobus } \\
\text { acidocaldarius } \\
\text { Sulfurococcus } \\
\text { mirabilis } \\
\text { Thermocladium } \\
\text { modestius } \\
\text { Thermococcus } \\
\text { zilligii } \\
\text { Thermoplasma } \\
\text { acidophilum }\end{array}$} & $\begin{array}{l}\text { Maksimum } \\
\text { Sicaklık }\left({ }^{\circ} \mathrm{C}\right)\end{array}$ & $\begin{array}{l}\text { Heterotrof } \\
\text { /Ototrof }\end{array}$ & Aerobik/Anaerobik \\
\hline & 65 & A & AN \\
\hline & 70 & A & AN \\
\hline & 60 & $\mathrm{H}$ & AN \\
\hline & 50 & $\mathrm{H}$ & $\mathrm{AN}$ \\
\hline & 88 & $\mathrm{H}$ & AN \\
\hline & 65 & $\mathrm{H}$ & AN \\
\hline & 80 & FA & FAN \\
\hline & 86 & FA & $\mathrm{AE}$ \\
\hline & 82 & $\mathrm{H}$ & FAN \\
\hline & 85 & $\mathrm{H}$ & $\mathrm{AN}$ \\
\hline & 63 & $\mathrm{H}$ & FAN \\
\hline
\end{tabular}

\section{Biyoteknoloji uygulamalarında arkelerin kullanımı}

Endüstrinin hemen her alanında kullanılan enzimler genellikle mikroorganizmalardan elde edilmektedir. Çünkü mikroorganizma kaynaklı enzimlerin bitkisel veya hayvan kaynaklı enzimlere göre katalitik aktivitelerinin çok yüksek olması, istenmeyen yan ürün oluşturmamaları, daha stabil ve ucuz olmaları, fazla miktarda elde edilebilmeleri gibi avantajları vardır. Arkelerin birçoğunun ekstrem koşullarda büyümesinden dolayı, bu organizmalardan izole edilen enzimlerin, pratik uygulamalarda kullanıldığında büyük avantaj sağlayabileceği düşünülmektedir. Arkelerin kullanıldığı alanlardan biri de metanojenlerin esas olarak metandan oluşan biyogaz ürettikleri kanalizasyon işlemleridir. Ek olarak termofilik arkeler, Metallosphaera sedula gibi termoasidofilik organizmaların katı sülfit minerallerine bağlandığı ve sonuçta altın ve bakır gibi metallerin salınmasıyla oksitlendiği düşük dereceli cevherlerin elde edilmesinde (Biomining) de kullanılmaktadır [14].

\subsection{Arkeal Ekstremozimlerin Biyoteknoloji Uygulamalarında Kullanımları}

Enzim üretiminde kullanılan mikroorganizmalar sadece enzim üretme yeteneklerine göre değil, toksik ve patojen olmamalarına göre de seçilmektedir. Özellikle son yıllarda stratejik alan şeklinde değerlendirilen rekombinant DNA teknolojisinden yararlanılarak enzim üretimi büyük boyutlara ulaşmış ve kullanımı giderek yaygınlaşmıştır [15]. Günümüzde, endüstriyel olarak önemli birçok kimyasal proses, yüksek sıcaklık ve basınç gibi sert koşullarda gerçekleştiğinden, bunlara alternatif ve çevresel etkisi daha az yöntemler için ekstrem koşullara dayanıklı enzimlere gerek duyulmaktadır. Son zamanlarda yapılan çalışmalara göre endüstriyel enzimlerin büyük çoğunluğu mezofilik mikroorganizmalardan sağlanmakta, ancak birçok avantaja sahip olmalarına karşın, uygulamalara dayanıksız olmaları nedeni ile kullanımları sınırlı kalmaktadır.[16] Öte yandan, ekstrem termofil mikroorganizmalardan elde edilen enzimler (ekstremozimler) ekstrem koşullara daha dayanıklı olduklarından, enzim üretimi için önemlidirler.

Arkelerin sıcaklık, tuzluluk ve pH sınırlarında işlev gösterme kabiliyetlerinin bir sonucu olarak, termofilik arkelerin ekstremofilik enzimleri veya ekstremozimleri birçok uygulamada kullanım alanı bulmaktadır ve çeşitli biyoteknolojik çalışmalarda kullanım için düşünülebilmektedir. Isıya dayanıklı ekstremozimler, $50^{\circ} \mathrm{C}$ 'nin üzerindeki sicaklıklarda en uygun şekilde büyüyen termofillerden veya $80^{\circ}$ C'nin üzerindeki optimum büyüme sıcaklıkları ile hipertermofillerden elde edilebilmektedirler. Ticari olarak kullanılan enzimlerin \%59'unu proteazlar, \%28'ini karbohidrazlar, \%3'ünü lipazlar ve \%10'unu ise diğer enzimler oluşturmaktadır. Termofilik ve hipertermofilik arkelerden elde edilen ekstremozimler ise; Glikozil hidrolazlar, Proteazlar, DNA ilişkili enzimler olarak sinıflandırılabilmektedir [17][18]. 


\subsubsection{Glikozil Hidrolazlar}

Bugüne kadar, termofilik ve hipertermofilik arkelerden çok sayıda $\alpha$ ve $\beta$ glikozil hidrolaz karakterize edilmiştir. Glikozil hidrolazlar, iki veya daha fazla karbonhidrat arasında veya karbonhidrat ile karbonhidrat olmayan kısımlar arasında glikozidik bağları hidrolize edebilen enzimler olarak tanımlanmaktadır. Her ne kadar glikozil hidrolazlar 85 familya arasında bölünse de bu enzimleri nişasta, ksilan veya selülozu hidroliz etme yeteneklerine göre; $\alpha$-1,4- ve $\alpha$-1,6-glikozidik bağlar (nişasta), $\beta$-1, 4-glikosidik bağlar (ksilan ve selüloz) içeren polimerler olarak gruplandirmak uygundur [17].

\section{Nişasta Parçalayıcı Enzimler}

$\alpha$-amilazlar nişastadaki $\alpha-1,4$ glikozidik bağları rasgele hidrolize ederek glukoz ve oligosakaritleri meydana getirir. Buna örnek olarak hipertermofilik arke türleri olan Pyrococcus woesi ve $P$. furiosus $\alpha$-amilazların $100^{\circ} \mathrm{C}$ sıcaklıkta en çok bilinen termofilik versiyonlarıdır. Thermococcus profundus DT5432'nin saflaştırıldığında $80^{\circ} \mathrm{C}$ optimum bir sicaklığa sahip olan amilaz $\mathrm{S}$ gibi termostabil $\alpha$-amilazlar ürettiği saptanmıştır. Termofilik ve hipertermofilik arkelerden izole edilen pullulanazlar ise, dallanmıs polimerlerde hem $\alpha-1,4$ hem de $\alpha-1,6$ glikozidik bağları hidrolize edebilen tip II sınıfına aittir. Bu gruba dahil olan bir diğer enzim $\alpha$-glukozidazlar, terminal glikoz kalıntılarını hidrolize eden glikojen yıkımının son aşamasında yer alır. Bu enzim, $105^{\circ} \mathrm{C}$ ve $115^{\circ} \mathrm{C}$ arasında en iyi şekilde çalışır. Termozim olarak da adlandırılan termofiliklerin enzimleri, optik nanosensörler ve analitlerin oluşturulmasında kullanılmaktadır [29]. Bunun yanısıra kâğıt endüstrisinde, süt endüstrisinde, boyalı ürünlerin işlenmesinde, deri endüstrisinde ve farmasötiklerde de kullanılmaktadır [19].

\section{Ksilan Parçalayıcı Enzimler}

Ksilanlar, $\beta-1,4$ bağlantılı D-xylopyranosyl alt birimlerinden oluşan bir ana zincire dayanan heterojen polisakkarid grubudur. Termostabil ksilanazlar, enzim destekli kâğıt ağartmasında kullanılmaktadır. Bunlara ek olarak meyve-sebze suları ve şarabın arıtılmasında, peynir olgunlaşması, hamur fermantasyonu gibi işlemlerde de rol oynamaktadır [19].

Tablo 2 Termofilik ve hipertermofilik arkelerin nişasta parçalayıcı enzimleri [17]

\begin{tabular}{|l|l|l|l|}
\hline Organizma & Enzim & $\mathbf{T}_{\text {optimal }}$ & $\mathbf{p H}_{\text {optimal }}$ \\
\hline D.mucosus & $\alpha$-amilaz & 100 & 5.5 \\
\hline P.furiosus & $\alpha$-amilaz & 100 & $6.5-7.5$ \\
\hline Pyrococcus sp. KOD1 & pullulanaz type II & 90 & 6.5 \\
\hline P.woesi & $\alpha$-amilaz & 100 & 5.5 \\
\hline Pyrodictium abyssi & $\alpha$-amilaz & 100 & 5.0 \\
\hline St.marinus & $\alpha$-amilaz & 100 & 5.0 \\
\hline S.solfaraticus & $\alpha$-amilaz & 100 & 5.0 \\
\hline S.solfaraticus MT-4 & glikoamilaz & 70 & 4.5 \\
\hline T.hydrothermalis & pullulanaz type II & 95 & 5.5 \\
\hline T.litoralis & pullulanaz type II & 98 & 5.5 \\
\hline T.profundus DT5432 & $\alpha$-amilaz (amilaz S) & 80 & $5.5-6.0$ \\
\hline $\begin{array}{l}\text { Thermococcus } \text { strain } \\
\text { AN-1 }\end{array}$ & $\alpha$-glikozidaz & 75 & 7.0 \\
\hline Thermococcus strain TY & $\alpha$-amilaz & 100 & 5.5 \\
\hline $\begin{array}{l}\text { Thermococcus strain } \\
\text { TYS }\end{array}$ & pullulanaz type II & 100 & 6.5 \\
\hline
\end{tabular}

\subsubsection{Proteazlar}

Proteazlar, proteinlerin yapısındaki peptid bağlarının hidrolitik parçalanmasını katalize eden enzimlerdir. Dünya çapında ticari ölçekte üretilen proteazlara, diğer enzimlere göre biyoteknolojik uygulamalarda daha fazla yer verilmektedir. Bu nedenle, ısıya dayanıklı arkeal proteazların izolasyonu ve karakterizasyonu büyük ilgi odağıdır. Proteaz enzimlerinin, diğer enzimlere göre yıllık olarak tüketilen oranları tablo 3 ’te verilmiştir [20][21]. 
Tablo 3 Mikrobiyal enzimlerin yıllık kullanım değerleri

\begin{tabular}{|l|l|}
\hline Enzim & Pazar Payı (\%) \\
\hline Alkali Proteazlar & 25 \\
\hline Diğer Proteazlar & 21 \\
\hline Amilaz & 18 \\
\hline Reninler & 10 \\
\hline Analitik Enzimler & 10 \\
\hline Karbohidrolazlar & 10 \\
\hline Lipaz & 3 \\
\hline Tripsin & 3 \\
\hline
\end{tabular}

Proteazlar, katalize ettikleri reaksiyon tipine göre ekzopeptidazlar ve endopeptidazlar olmak üzere iki gruba ayrılır. Bu tanımlamada belirleyici olan enzimlerin substratta etkili oldukları bölgedir. Çoğunlukla serin proteaz tipinde olan termofilik ve hipertermofilik arkelere ait çeşitli proteolitik enzimler tanımlanmıştır. Bu enzimler katalitik aktivitelerini sadece yüksek sıcaklıklarda değil, aynı zamanda deterjan veya diğer denatüre edici ajanların varlığında da gösterirler [22][17].

Tablo 4 Termofilik ve Hipertermofilik Arkelerin Proteaz Enzimleri [17]

\begin{tabular}{|l|l|l|l|}
\hline Organizma & Tip & $\mathbf{T}_{\text {optimal }}$ & $\mathbf{p H}_{\text {optimal }}$ \\
\hline A.pernix K1 & $\begin{array}{l}\text { Serin proteaz } \\
\text { (pernilaz) }\end{array}$ & 90 & $6.5-10.5$ \\
\hline $\begin{array}{l}\text { Desulfurococcus } \text { strain } \\
\text { Tok }_{12} \text { S }_{1}\end{array}$ & Serin proteaz & 95 & 7.5 \\
\hline Desulfurococcus strain SY & Serin proteaz & 85 & 7.5 \\
\hline Py.aerophilum & $\begin{array}{l}\text { Serin proteaz } \\
\text { (aerolizin) }\end{array}$ & $85-90$ & 7.5 \\
\hline P.furiosus & $\begin{array}{l}\text { Serin proteaz } \\
\text { (prolizin) }\end{array}$ & 110 & 6.3 \\
\hline Pyrococcus sp. KOD1 & Thiol proteaz & 90 & 7.0 \\
\hline St.marinus & Serin proteaz & 90 & 9.0 \\
\hline S.solfaraticus & Karboksi peptidaz & 85 & $6.5-8.0$ \\
\hline S.acidocaldarius & Asidik proteaz & 90 & 2.0 \\
\hline T.litoralis & Serin proteaz & 85 & 9.5 \\
\hline T.aggregans & Serin proteaz & 95 & 7.0 \\
\hline T.celer & Serin proteaz & 95 & 8.5 \\
\hline T.stetteri & Serin proteaz & 85 & 9.5 \\
\hline
\end{tabular}

Proteazlar endüstriyel ve biyoteknolojik uygulamalarda, örneğin kozmetik ve farmasötik sektöründe yaygın olarak kullanılmaktadır.

\subsubsection{DNA İlişkili Enzimler}

Son 40 yilda moleküler biyolojideki en önemli gelişmelerden biri, polimeraz zincir reaksiyonunun (PCR) gelişmesidir. Termostabil DNA polimerazlar çeşitli moleküler biyolojik uygulamalarda büyük rol oynarlar. Pyrococcus (Pfu) veya Thermus (Taq) cinsi prokaryotlardan elde edilen arkeal polimerazlar moleküler uygulamalarda yaygın olarak kullanılmaktadır. Hipertermofilik arke olan Thermococcus kodakaraensis KOD1'den DNA polimeraz enzimi üretilmiştir. KOD DNA polimeraz PCR'da bilinen en yüksek uzatma ve doğruluk oranını, göstermiştir [22]. 
Tablo 5 KOD DNA polimeraz,Pfu DNA polimeraz ve Taq DNA polimeraz karşılaştırması [23]

\begin{tabular}{|l|l|l|l|}
\hline Enzim & KOD DNA Polimeraz & Pfu DNA Polimeraz & Taq DNA Polimeraz \\
\hline Tür & Thermococcus kodakaraensis & Pyrococcus furiosus & Thermus aquaticus YT-1 \\
\hline Doğruluk & 0.0035 & 0.0039 & 0.013 \\
\hline Uzama Oranı & $106-138$ & 25 & 61 \\
\hline
\end{tabular}

DNA polimerazlara ek olarak, hipertermofilik arkeler diğer DNA modifiye edici enzimlerin de kaynağıdır. $T$. acidophilum'dan elde edilen termoaktif polimeraz (Thermo Sequenase) ve termostabil pirofosfataz kombinasyonunun kullanılması, daha uzun ve daha doğru dizi okumalarının belirlenmesini sağlar [23].

\section{Sonuçlar ve tartışma}

2006'da Karl O. Stetter [5] yayınladığı araştırmada; Woese ve Zillig'in arkelerle ilgili yaptıkları çalışmalardan yola çıkarak hipertermofilik türler üzerine bir araştırma yürütmüştür. 1972'ye kadar en yüksek büyüme sıcaklığına sahip mikroorganizma Sulfolobus acidocaldarius idi. 1977'de Carl Woese yaşamın domainlerine Arke'yi eklediğinde bu türün arke domainine ait olan bir hipertermofilik organizma olduğu ortaya çıkmıştır. Stetter, Kerlingarfjo“1l dağındaki kaynar su ve çamur örnekleri ile çubuk şekilli bir metanojen olan Methanothermus fervidus'u izole etmiştir. $\mathrm{Bu}$ organizma $97{ }^{\circ} \mathrm{C}^{\prime}$ ye kadar bir sicaklıkta büyümüş ve $82^{\circ} \mathrm{C}^{\prime}$ de en hızlı (optimal) büyümesini sergilemiştir. Sulfolobus acidocaldarius'tan çok daha yüksek sıcaklıklarda hayatta kalabilmiştir. Bunun yanısıra Stetter ve Zillig 1981 (21) 'de anaerobik Thermoproteals'in ilk üyelerini izole etmişlerdir. Methanothermus'a benzer şekilde, Thermoproteales 97 C'ye kadar büyüme sıcaklığı sergilemiş ve $65 \mathrm{C}$ veya daha düşük sıcaklıkta büyüyemiştir. Bunu takiben 1981 'de Vulcano Adası'ndaki (İtalya) $100^{\circ}$ C'nin üzerindeki sıcaklıkta Porto di Levante'deki sıcak deniz tabanında yer alan bir denizaltı solfatarik alanından örnekler almıştır. İzole edilen örneklerden belirlenen mikroorganizmalar $100{ }^{\circ} \mathrm{C}$ 'nin üzerinde gelişim göstermişlerdir.

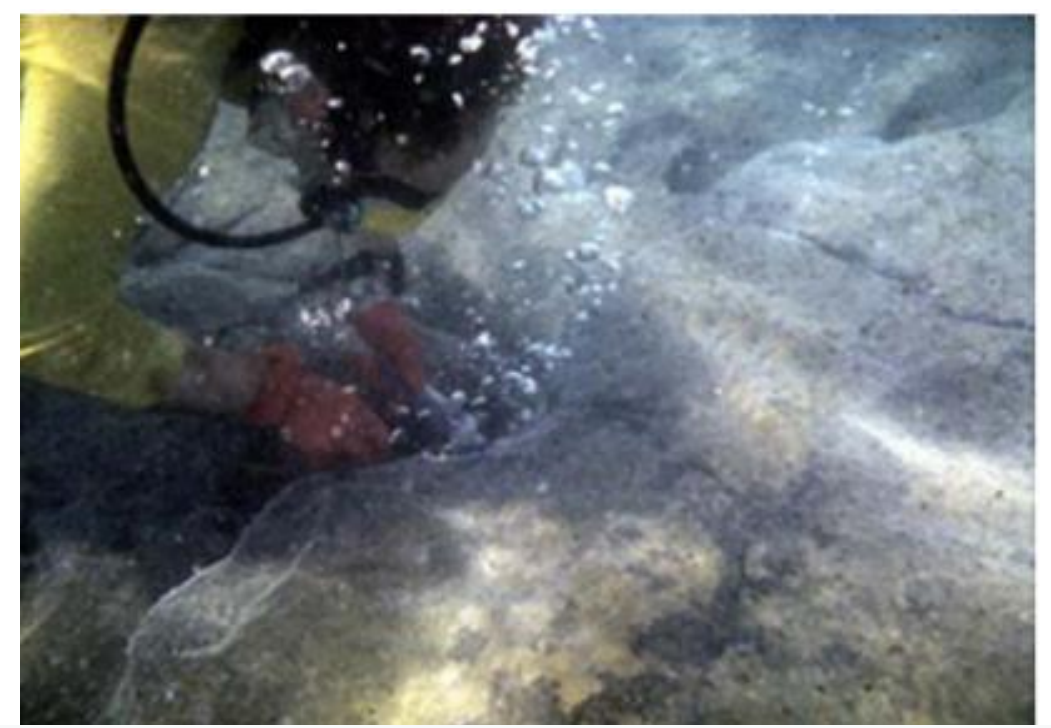

Şekil 6. Porto di'deki denizaltı hidrotermal deliklerinden numune alınan Levante, Vulcano, İtalya [5]

Böylece Stetter, Volcano'ya adapte olmuş ilkel yaşam tarzlarına dayanarak, benzer hipertermofilik organizmaların 3,9 milyon yıl önceden beri Dünyada var olabileceği hipotezini gündeme getirmiştir. Buna dayanarak bu heyecan verici hipertermofillerin daha fazlasını bulmak için, son 25 yıl boyunca dünyanın her yerindeki yüksek sıcaklık alanlarını ziyaret etmiş ve oradan yüksek sıcaklık organizmalarını izole etmiştir. 


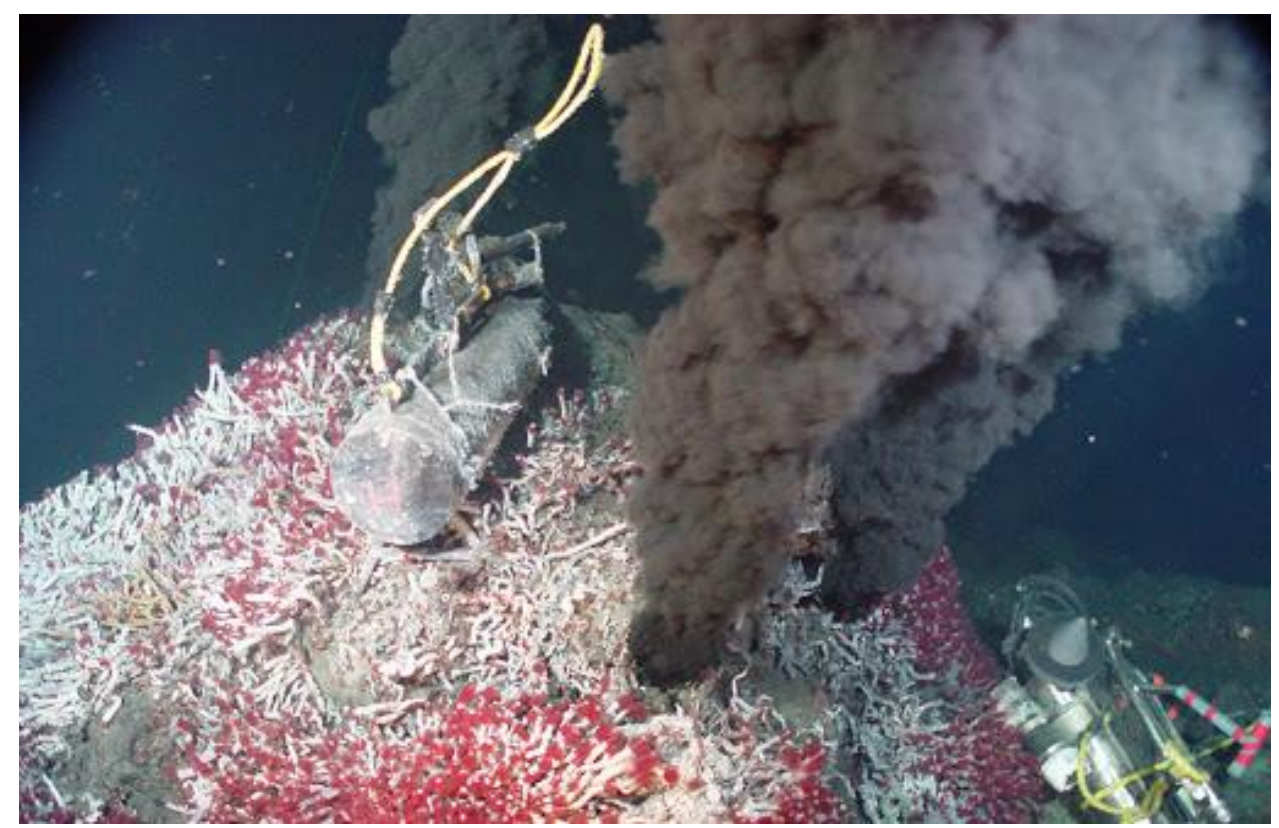

Şekil 7. Hidrotermal bacalar

Muhteşem denizaltı bacaları ile derin deniz hidrotermal bacaları dahil bu sitelerin birçoğunu ziyaret etmiştir. Buna ek olarak, derin yeraltı (volkanik olmayan) jeotermal olarak ısıtılan petrol taşıyan kumtaşı ve kireçtaşı içinde, Kuzey Denizi'nin tabanından ve Alaska Kuzey yamaç permafrostunun yüzeyinin yaklaşık $3.500 \mathrm{~m}$ altında in situ sıcaklıklara sahip hipertermofilik toplulukları keşfetmiş̧ir. Stetter laboratuvarında bu türlerle birlikte 50 yeni farklı hipertermofilik tür izole etmiş ve tanımlamıştır.

Arkelerin ekstrem ortamlarda hayatta kalabilme kabiliyetlerinin varlığı çeşitli enzimlerin biyoteknoloji alanında kullanımında yararlar sağlamaktadır. Çoğunlukla, sadece arkeal toplulukların varlığı önemli bir ekonomik değer taşımaktadır. Metanojenik arkeler, temiz ve ucuz enerji kaynağ kapasitelerine sahipken, asidofilik arkeler, mineral-sülfür oksitleyici yeteneklerinin jeokimyasal sülfür döngüsünde önemli bir rol oynadığı çeşitli asit maden drenaj sahalarında tanımlanmıştır. Her ne kadar arkelerle ilgili çeşitli ürünler önemli ticari değer taşıyorsa da, biyoteknolojik olarak yararlı arkeal enzimler endüstriyel ilginin ana odağını temsil etmektedir [5].

2017'de Kelly Dumorné [19] ve arkadaşlarının yürütttüğü çalışmada arkeal ekstremozimlerin endüstriyel uygulamalardaki öneminden bahsedilmektedir. Çalışmada; termofilik proteinler, piezofilik proteinler, asidofilik proteinler ve halofilik proteinlerin biyoteknolojik ve endüstriyel uygulamaları için daha fazla dikkat çektiği vurgulanmaktadır. Son yıllarda, özellikle ekstremofillerden gelen enzimler ve birçok süreçte enzimlerin önemi araştırılmıştır. Çoğunluğun biyoteknolojik ve endüstriyel uygulamalar için kullanıldığı çok sayıda enzim tanımlanmıştır (3.000'den fazla), ancak enzim pazarı hala endüstri taleplerine cevap vermek için yetersizdir. Bu durumun temel nedeni, birçoğunun endüstriyel koşullara dayanmamasıdır. Ayrıca, enzimler ekolojik süreçleri kullanan teknolojilerde kullanılmaktadır. Endüstriyel işlem, yüksek tekrarlanabilirlik ve diğer parametrelerle $\mathrm{pH}$, sıcaklık ve havalandırmanın farklı koşullarına dayanabilen biyokatalizörlere ihtiyaç duyar. Ekstremofilik mikroorganizmalar, biyolojik olarak bozunabilirlikleri ve aşırı kararlılıkları nedeniyle çok çeşitli endüstriyel uygulamalara sahip ekstremozimlerın kaynağıdır.

Bunun yanı sıra mikrobiyal çeşitlilik çalışmalarında son yıllarda arkeler önemli bir rol oynamaktadır. Mikrobiyal çeşitliliğin belirlenmesinde kullanılan kültürden bağımsız yöntemlerle pek çok farklı molekül (DNA, RNA vb) ve /veya yaklaşım seçilebilmektedir. Farklı habitatların prokaryotik çeşitlilikleri hem mikrobiyolojik kültür temelli hem de moleküler yöntemlere bağlı yaklaşımlar kullanılarak belirlenebilmektedir. Kültür temelli yöntemlerin kullanılabilmesi mikrobiyal canlılığa bağlı olduğu için ekstrem koşullarda hayatta kalmaya adapte arke türlerini laboratuvar koşullarında canlı tutmak her zaman mümkün olmamaktadır. Pace ve arkadaşları ilk olarak 1986'da ssurRNA'lar için tasarlanan primerleri kullanarak PCR yöntemiyle çevresel araştırmalara başlamışlardır (Pace ve ark., 1986). Doksanlı yıllardan itibaren kullanılmaya başlanan PCR-bazlı ve örneklerden direkt $16 \mathrm{~S} r D N A$ ların çoğaltıldığı moleküler yöntemler sayesinde çeşitli habitatlardaki bakteri ve arkeleri (eğer önceden tanıları yapılmış ve veri tabanına girilmişse) genus/tür bazında tespit etmek mümkündür. Ekstrem çevrelerdeki arkeal çeşitliliğin belirlenmesi için yapılmış çeşitli çalışmalar mevcuttur.

2010'da Malkawı tarafindan yürütülen çalışmada Ürdün kaplıca sularında bakteri ve arkea çeşitliliği kültürden bağımsız olarak tespit edilmiştir. Farklı kaynaklardan 5 örnekte termofilik ve hipertermofilik arke türlerine rastlanmıştır [24]. 2014'te Budakoğlu ve ark. Acıgöl'ün Archael mikrobiyal çeşitliliği çalışmasına göre; TA klonlama yöntemi kullanılarak yapılan çalışmada toplamda 50 koloni seçilmiş ve sekanslanan mikroorganizmaların tümünün Halofilik mikroorganizmalara ait olduğu belirlenmiştir [25]. 
2016'da Çınar ve arkadaşları Doğu Anadolu bölgesinde (Sivas, Erzincan, Bingöl) bulunan 4 farklı tuzlada prokaryotik çeşitlilik analizi gerçekleştirmişlerdir. Genellikle halofilik arkeler tespit edilirken bunun yanı sıra halotolerant mikroorganizmalara da rastlanmıştır [26].

2017'de Pektaş ve Temel'in gerçekleştirdiği çalışmada Denizli'de bir sülfidik mağara olan Kaklık mağarasından alınan örneklerde mikrobiyal çeşitlilik araştırılmıştır. Çalışmada 16S rRNA geni için pyrosequencing tekniği kullanılmıştır. Toplamda 3 arkeal filum ve 25 bakteriyal filum tespit edilmiş ve arke sekansları içerisinde Thermoplasmata tüm örnekleme alanlarında en bol bulunan grup olarak belirtilmiştir [27].

2018'de Güven ve arkadaşları Türkiye'nin ekstrem çevrelerinden alınan kaynaklarda termofilik ve halofilik mikroorganizmaların izolasyonu ve tanımlanmasını amaçlamışlardır. İncelenen termofilik bakteriler; Anoxybacillus, Geobacillus, Bacillus, Brevibacillus ve Bacillaceae familyasına ait Aeribacillus ve Thermus ve Thermomonas gibi termofillerdir. Halofilik mikroorganizmaların ise genelini arkeler oluşturmuştur [28].

Sonuç olarak bu derlemede ekstrem çevrelere uyum sağlayan arkelerin biyoçeşitliliğine ve bu mikroorganizmalardan elde edilen enzimlerin endüstriyel uygulamalarına odaklanılmıştır. Dünyada ve ülkemizde özellikle termofilik/hipertermofilik arkeal çeşitlilik çalışmalar sınırlı sayıdadır ve gelecekte bu mikroorganizmalara odaklanılmasında derlememiz aydınlatıcı bir nitelik taşımaktadır. Ek olarak ekstrem koşullarda iş görebilen, endüstride zorlayıcı koşullarda mezofilik enzimlerine göre üstünlük sağlayan termofilik arkelerin enzimlerinin araştırılması biyoteknolojide öncelikli bir hedef olmaya devam etmektedir.

\section{Kaynaklar}

[1] Lever, M. A., Teske, A. P. (2015). Diversity of methane-cycling archaea in hydrothermal sediment investigated by general and group-specific PCR primers. Applied and Environmental Microbiology, 81(4), 1426-1441.

[2] Garrett, R.A., Klenk, H. P. (2007). Archaea: evolution, physiology, and molecular biology. Blackwell Publishing, Oxford, United Kingdom.

[3] Spang,A., Caceres, E. F., Ettema, T. J. G. (2017). Genomic exploration of the diversity, ecology, and evolution of the archaeal domain of life. Science, 357, (6351).

[4] Aslan, Z. (2019). Termal kaynaklardan izole edilen bakterilerin enzimleri üzerine çalışmalar (Master's thesis).

[5] Stetter, K. O. (2006). History of discovery of the first hyperthermophiles. Extremophiles, 10(5), 357-362.

[6] Merkel, A. Y., Podosokorskaya, O. A., Chernyh, N. A., Bonch-Osmolovskaya, E. A. (2015). Occurrence, diversity, and abundance of methanogenic archaea in terrestrial hot springs of Kamchatka and Saõ Miguel Island. Microbiology, 84(4), 577-583.

[7] Barahona, S., Cortés, J., Hengst, M., Dorador, C., Remonsellez, F. (2017). Diversity of Thermophilic IronPyrite-Oxidizing Enrichments from Solfataric Hot Springs in the Chilean Altiplano. In Solid State Phenomena, 262, 526-530.

[8] Moore,T.A. (2012). Coalbed methane: A review. International Journal Of Coal Geology, 101, 36-81.

[9] Lebeis,S. L. (2014). The potential for give and take in plant-microbiome relationships. Frontiers In Plant Science, 5, 287.

[10] Pace, N. R., Stahl, D. A., Lane, D. J., Olsen, G. J. (1986). The analysis of natural microbial populations by ribosomal RNA sequences. In Advances In Microbial Ecology, 1-55.

[11] Aouad, M., Taib, N., Oudart, A., Lecocq, M., Gouy, M., Brochier-Armanet, C. (2018). Extreme halophilic archaea derive from two distinct methanogen Class II lineages. Molecular Phylogenetics and Evolution,127, 4654.

[12] Guzzo, J. (2012). Biotechnical applications of small heat shock proteins from bacteria. International Journal Of Biochemistry Cell Biology, 44 (10),1698-1705.

[13] Silva, S. B., Pinheiro, M. P., Fuzo, C. A., Silva, S. R., Ferreira, T. L., Lourenzoni, M. R., Ward, R. J. (2017). The role of local residue environmental changes in thermostable mutants of the GH11 xylanase from Bacillus subtilis. International journal of biological macromolecules, 97, 574-584.

[14] Norris, P. R., Burton, N. P., Foulis, N. A. (2000). Acidophiles in bioreactor mineral processing. Extremophiles, 4(2), 71-76.

[15] Wiseman, A., Dalton, H. (1987). Enzymes versus enzyme-mimetic systems for biotechnological applications. Trends In Biotechnology, 5(9), 241-244.

[16] Schocke, L., Bräsen, C., Siebers, B. (2019). Thermoacidophilic Sulfolobus species as source for extremozymes and as novel archaeal platform organisms. Current Opinion İ Biotechnology,59, 71-77.

[17] Cabrera, M. Á., Blamey, J. M. (2018). Biotechnological applications of archaeal enzymes from extreme environments. Biological Research, 51.

[18] Amoozegar, M. A., Siroosi, M., Atashgahi, S., Smidt, H., Ventosa, A. (2017). Systematics of haloarchaea and biotechnological potential of their hydrolytic enzymes. Microbiology, 163(5), 623-645.

[19] Herrero-Fresno, A., Espinel, I. C., Spiegelhauer, M. R., Guerra, P. R., Andersen, K. W., Olsen, J. E. (2018). The homolog of the gene bstA of the BTP1 phage from Salmonella enterica serovar Typhimurium ST313 is an antivirulence gene in Salmonella enterica serovar Dublin. Infection and Immunity, 86(1). 
[20] Chakdar, H., Kumar, M., Pandiyan, K., Singh, A., Nanjappan, K., Kashyap, P. L., Srivastava, A. K. (2016). Bacterial xylanases: biology to biotechnology. 3 Biotech, 6(2), 150.

[21] Szilágyi, A., Závodszky, P. (2000). Structural differences between mesophilic, moderately thermophilic and extremely thermophilic protein subunits: results of a comprehensive survey. Structure, 8(5), 493-504.

[22] Leigh, J. A., Albers, S. V., Atomi, H., Allers,T. (2011). Model organisms for genetics in the domain Archaea: Methanogens, halophiles, Thermococcales and Sulfolobales. FEMS Microbiology Reviews, 35(4), 577-608.

[23] Takagi, M. (1997). Characterization of DNA polymerase from Pyrococcus sp. strain KOD1 and its application to PCR. Applied and Environmental Microbiology, 63(11), 4504-4510.

[24] Malkawi, H. I., Al-Omari, M. N. (2010). Culture-dependent and culture-independent approaches to study the bacterial and archaeal diversity from Jordanian hot springs. African Journal of Microbiology Research, 4(10), 923-932.

[25] Budakoglu, M., Kurt, H., Karaman, M., Kumru, M., Kumral, M., Akarsubaşi, A. T. (2014). Archaeal microbial diversity of hypersaline Lake Acıgöl, Denizli, Turkey. Geomicrobiology Journal, 31(6), 454-460.

[26] Çinar,S., Mutlu, M.B. (2016). Comparative analysis of prokaryotic diversity in solar salterns in eastern Anatolia (Turkey). Extremophiles, 20(5), 589-601.

[27] Gulecal-Pektas, Y., Temel, M. (2017). A Window to the subsurface: Microbial diversity in hot springs of a sulfidic cave (Kaklik, Turkey). Geomicrobiology Journal, 34(4), 374-384.

[28] Guven, K., Bekler, F. M., Guven, R. G. (2018). Thermophilic and Halophilic Microorganisms Isolated from Extreme Environments of Turkey with Potential Biotechnological Applications. In Extremophiles In Eurasian Ecosystems: Ecology, Diversity, and Applications, 219-264.

[29] Yücelşengün, İ,Garg1, A. (2020). Comparative Study of Total Phenolic Contents, Antioxidant and Antimicrobial Activities of Different Extracts of Corchorus olitorius L. Growing in North Cyprus. Biological Diversity and Conservation, 13(3), 298-304. 